\title{
Employee outcomes of supporting and valuing diversity: mediating role of diversity climate
}

\author{
Sadia Mansoor, Phuong Anh Tran and Muhammad Ali \\ Queensland University of Technology, Brisbane, Australia
}

\begin{abstract}
Purpose - Diversity management is gaining attention in the organizations. This study aims to theorize and test a model linking efforts to support diversity and organizational value of diversity with job satisfaction and organizational identification and to propose that these relationships are mediated by an organization's diversity climate.
\end{abstract}

Design/methodology/approach - Employee survey was used to collect data from employees at an Australian manufacturing organization. Structural equation modelling in AMOS was performed for the proposed model, controlling for age and gender.

Findings - The mediating role of diversity climate in the relationship of organizational value of diversity and outcomes (job satisfaction and organizational identification) is significant. The authors discuss theoretical, research and practical contributions.

Originality/value - The present study extends the literature by testing a mediation model derived from the signalling and social exchange theories.

Keywords Job satisfaction, Organizational identification, Diversity climate, Efforts to support diversity, Organizational value of diversity

Paper type Research paper

\section{Introduction}

The United Nations sustainable development goals include an inclusive world by 2030 (United Nations, 2020). Managing diversity is also increasingly seen by key stakeholders, including customers, regulators and shareholders, as a socially responsible behaviour (Klarsfeld, Ng \& Tatli, 2012). Growing societal expectations with respect to diversity have urged organizations to formally integrate diversity in organizational identity through policies and procedures (Cole \& Salimath, 2013). Indeed, key to successfully establishing a supportive work environment is not only the organization's efforts to foster diversity in the workplace, but valuing diversity is also vital and needs to percolate throughout the organization (Gilbert \& Ivancevich, 2000; Hopkins, Hopkins \& Mallette, 2001; Ng \& Sears, 2018). The percolation may occur when the organization focuses on putting its support and value towards diversity into practice, which in turn should come with effects on employees' impressions of the organization's diversity climate (Herdman \& McMillan-Capehart, 2010).

(C) Sadia Mansoor, Phuong Anh Tran and Muhammad Ali. Published in Organization Management Journal. Published by Emerald Publishing Limited. This article is published under the Creative Commons Attribution (CC BY 4.0) licence. Anyone may reproduce, distribute, translate and create derivative works of this article (for both commercial and non-commercial purposes), subject to full attribution to the original publication and authors. The full terms of this licence maybe seen at http:// creativecommons.org/licences/by/4.0/legalcode
Diversity climate

Received 24 September 2019 Revised 2 February 2020 12 May 2020 20 July 2020 Accepted 9 September 2020 
OMJ 18,1

In the same line of thought, we examine how perceived efforts to support diversity and organizational value of diversity can act as antecedents to diversity climate, which, in turn, generates important employee outcomes, including job satisfaction and organizational identification. The signalling theory (Spence, 1973) and social exchange theory (Blau, 1964) are drawn upon in our development of the conceptual framework. The basic tenets of the signalling theory (Bowen \& Ostroff, 2004) are applied: an organization's diversity practices send signals to employees about organizational value and efforts dedicated to promoting diversity.

In this paper, efforts to support diversity is defined as the practices of an organization that demonstrate the organization's promotion and endorsement of diversity (Triana \& García, 2009). Organizational value of diversity refers to diversity-related values and beliefs espoused by an organization (Avery, McKay, Wilson \& Tonidandel, 2007). In addition, we examine how this relationship can be mediated by diversity climate. Our literature review reveals that widely varying definitions of diversity climate have emerged. This paper uses the definition suggested by Gonzalez and Denisi (2009) who used the term to refer to "aggregate member perceptions about the organization's diversity-related formal structure characteristics and informal values" (p. 24). This definition is based on the pioneering work of Kossek and Zonia (1993), who brought together the two concepts of diversity and climate, and defined diversity climate as "general perception toward the importance of employer efforts to promote diversity" (p. 63).

Extant literature has focused on antecedents of diversity climate (Pugh, Dietz, Brief \& Wiley, 2008). Kossek, Markel and Mchugh (2003), e.g. examined diversity climate at the organizational level and found some evidence of the positive relationship between levels of gender and racial heterogeneity and diversity climate. Additionally, human resource (HR) policies and practices have been found to be predictive of the formation of diversity climate, as noted in diversity management literature (Gonzalez \& Denisi, 2009; Herdman \& McMillan-Capehart, 2010). Kim and Gelfand (2003), for instance, found that hiring practices that take account of one's racioethnic identity form a favourable impression of an organization's commitment to workplace diversity. Although Kim and Gelfand's study was not designed to measure diversity climate, its finding corroborates the notion that individuals are typically attentive to organizational policies and practices to denote the overall climate of diversity. An organizational-level investigation conducted by Herdman and McMillan-Capehart (2010) provides insight into the intricate relationship between diversity initiatives/efforts and diversity climate, suggesting that this relationship is strengthened when the management team is more racially heterogeneous and demonstrates higher levels of managerial relational values (i.e. beliefs regarding the strategic importance of employees). Additionally, recognizing the major influence of efforts to support diversity on changes in employee perceptions, Herdman and McMillan-Capehart acknowledge the association of diversity climate with organizationally important outcomes.

At the organizational level, diversity climate has been reported to act as a moderator in the relationship between organizational heterogeneity and its productivity and return on profit (Gonzalez \& DeNisi, 2009). The exigency for organizations to better understand how to cultivate a more diverse and inclusive workplace and to best approach issues associated with workforce diversity continues to grow. This has led to a proliferation of management studies on the impact of diversity climate on individuals, dyads, groups and organizations (Cole, Jones \& Russell, 2016; Dwertmann \& Boehm, 2016; Gonzalez \& Denisi, 2009; Holly Buttner, Lowe \& Billings-Harris, 2010; Nishii, 2013). There is an assumption held by many researchers and managers that if employees feel valued and adequately supported by their organization, this will result in positive employee outcomes, including job satisfaction and 
organizational identification (Bettencourt \& Brown, 1997; Hicks-Clarke \& Iles, 2000; Mor Barak \& Levin, 2002). Job satisfaction refers to enjoyment or positive emotion as a result of an evaluation of one's job or job experiences (Locke, 1976). Organizational identification refers to "the perception of oneness with or belongingness" to an organization (Ashforth \& Mael, 1989, p. 34). Such perception results from an alignment between one's organizational membership and his or her self-concept, which could be cognitive (e.g. internalizing organizational values), emotional (e.g. taking pride in being part of the organization) or both (Riketta, 2005).

Despite extant literature, it is still unknown whether efforts to support diversity and organizational value of diversity could influence individual perceptions of diversity practices. Therefore, the present study extends the literature by pretesting and testing a theoretical model (Figure 1), linking efforts to support diversity and organizational value of diversity with job satisfaction and organizational identification, and proposes that this relationship is mediated by diversity climate. Individual-level factors, such as employees' views of an organization's diversity-related policies and values, are deemed to be constituents for evaluating the organization's climate for diversity (Mor Barak, Cherin, \& Berkman, 1998). The study draws on the signalling and social exchange theories to develop hypotheses. The paper unfolds as follows. First, based on the signalling principles, we argue that organizational efforts and value with respect to diversity are positive predictors of the emergence of diversity climate. Second, a positive association of diversity climate with job satisfaction and organizational identification is proposed, drawing on the social exchange theory. Third, mediating relationships are proposed based on the integration of the signalling and social exchange theories. This is followed by the presentation of the results after testing these predictions in an Australian manufacturing organization. Finally, the study's theoretical, research and managerial implications are discussed.

\section{Theoretical underpinnings and hypotheses development}

\section{Efforts to support diversity, organizational value of diversity and diversity climate}

The theoretical justification for connecting efforts to support diversity and organizational value of diversity to diversity climate in the present study is grounded in the process emphasized by the signalling theory - communication under conditions of information asymmetry between two parties (Spence, 2002). The signalling theory posits that employee perceptions of an organization's objectives and attributes, including policies, procedures and practices, are shaped by the organization's cues and signals (Spence, 1973). Cues refer to organizational aspects noticed by employees. Signals refer to organization-delivered messages (Avery et al., 2007). Propositions based on the signalling theory suggest that, due to the incomplete information about an organization, employees form perceptions about the organization's characteristics from visible cues and signals the organization attempts to provide (Turban \& Greening, 1997).

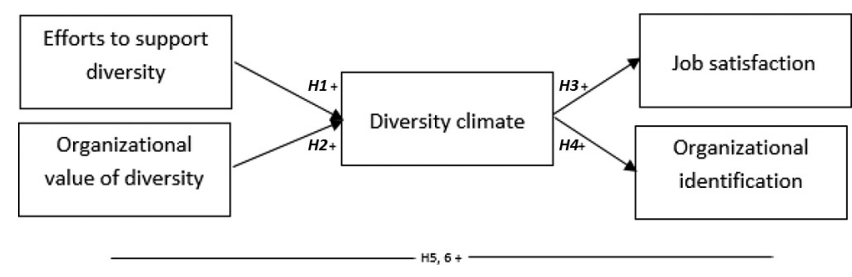

Diversity climate

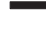


OMJ 18,1

We argue that employees receive signals from the organization in the form of efforts they make to support diversity and the organizational value towards diversity. In this process, organizational members assign meanings to organizational events, practices and procedures that they experience. Such meanings are aggregated and constitute the organizational diversity climate (Schneider \& Reichers, 1983). Indeed, employees pay attention to what they encounter and the surroundings within their organization, and consequently reach conclusions about the priorities and values upheld by their organization (Schneider, Gunnarson \& Niles-Jolly, 1994). For example, employees develop general views regarding the extent to which management values their contributions based on their experience of reward management systems. Favourable types of rewards, including recognition, pay and promotions, have been found to be identified by employees as indicators of management's positive assessment and appreciation of their contributions (Rhoades \& Eisenberger, 2002). Another example is related to employees' perceptions of organizational work-life supportiveness, based on their evaluation of their work demands, including work hours and overload, and resources, available in their work environment such as job security, flexibility, supervisor and work-group support. Employees' experiences of decreased work demands and increased resources were found to affect their impressions of organizational values of work-life balance and the degree to which the organization supports work-life integration (Valcour, Ollier-Malaterre, Matz-Costa, Pitt-Catsouphes \& Brown, 2011). A large body of literature has applied the signalling theory to elucidate communicative dimensions in a wide range of organizational contexts. For instance, diversity scholars have advanced our understanding of how organizations use board diversity as a signal to stakeholders regarding organizational interests in upholding social values (Miller \& Del Carmen Triana, 2009). Similarly, signalling perspectives have been widely incorporated in recruitment research to show how applicants use information, or signals, which they encounter during the recruitment process to make inferences about the attributes of an organization (Rynes, Bretz \& Gerhart, 1991; Suazo, Martínez \& Sandoval, 2009). Common attributes entail vision and mission statements, organizational values and goals, employee testimonials, organizational initiatives, information regarding compensation, employee benefits and job requirements (Cober, Brown, Blumental, Doverspike \& Levy, 2000).

Additionally, previous studies underscore the symbolic role of $\mathrm{HR}$ practices in revealing organizational values and priorities (Guzzo, Noonan \& Elron, 1994; Tsui, Pearce, Porter \& Tripoli, 1997). Diversity practices, or efforts, within an organization serve as signals of its commitment to support employees from all backgrounds (Downey, Werff, Thomas \& Plaut, 2015). In their study of the sources of diversity climate, Herdman and McMillan-Capehart (2010) advocate the merits of the signalling theory in explaining how establishing diversity programmes influences diversity climate. They contend that diversity schemes, as part of HR policies and practices, indicate principal attributes of an organization and, hence, influence diversity climate. An organization's investments in support of diversity serve as signals of the organization's commitment to improving and promoting diversity (Avery et al., 2007). Examples include diversity training programmes (Shen, Chanda, D'Netto, \& Monga, 2009), mentoring programmes for women and minorities and affinity networks. These types of investments serve to communicate organizational efforts to foster diversity and inclusion in the workplace (Cundiff, Nadler \& Swan, 2009; Dobbin, Kalev \& Kelly, 2007; Shen et al., 2009). Similar arguments have been presented in regard to the extent to which an organization is identified to be fair and supportive of its employees (Edwards \& Peccei, 2010), in that perceptions of an organization's procedural fairness (Tyler \& Blader, 2003) and support (Edwards, 2009; Sluss, Klimchak, \& Holmes, 2008) indicate that employees are valued and respected. In turn, employees tend to form an impression of how genuine and 
supportive the organization is towards diversity in the presence of its diversity-related efforts and values (Kossek \& Zonia, 1993; Mor Barak et al., 1998). Following this line of reasoning, efforts to support diversity and organizational value of diversity should be positively associated with diversity climate:

H1. Perceived efforts to support diversity will have a positive relationship with diversity climate.

Diversity

climate

H2. Organizational value of diversity will have a positive relationship with diversity climate.

\section{Diversity climate, job satisfaction and organizational identification}

The relative deprivation theory, social identity theory, self-categorization theory and intersectionality theory predict detrimental outcomes of diversity characteristics (Mor Barak et al., 2016). As individuals tend to categorize and compare themselves into in- and outgroup members based on similarities and differences, individuals who belong to more than one under-represented group feel more neglected and left out. Therefore, it is important for the organizations to maintain a favourable diversity climate. The social exchange theory predicts the behaviour of employees in response to inequitable diversity climate. It is premised on relational processes between individuals (or parties) with reciprocal attitudes and behaviours (Blau, 1964). Social exchange can be characterized as human interaction incurred as a result of actions initiated by the participating individuals and which purportedly creates a sense of obligation to return the favours or gestures of goodwill to equalize the exchange (Cropanzano \& Mitchell, 2005). Different views have been expressed regarding the nature of the exchange process (Cropanzano, Anthony, Daniels \& Hall, 2017). For instance, Blau (1964) suggests that an exchange consists of discretionary transactions and leads to social outcomes that are of mutual concern to the parties. Alternatively, as noted by Gould-Williams (2007), social exchange may entail legally enforceable contracts, based on mutually agreed economic principles that the parties involved in the contracts arrive at and are bound by. These dissimilar views, however, converge on the notion that social exchange is based on mutual trust, loyalty and commitment that dictate the parties' adherence to certain exchange guidelines (Cropanzano \& Mitchell, 2005).

The social exchange theory has been widely applied in the management literature to operationalize employee-organization exchange relationships (Bal, Chiaburu \& Jansen, 2010). The present study draws from the social exchange theory to infer why diversity climate may contribute to positive organizational behaviours (e.g. job satisfaction and organizational identification) through the employee-organization exchange relationship. Job satisfaction and organization identification are important work attitudes that are purported to benefit performance and overall organizational success. Organizational research has substantiated that positive job satisfaction and identification with a particular organization are strongly aligned with a wide range of organizationally relevant outcomes, including turnover intention (Cole, Bruch, Dick, Becker \& Meyer, 2006; De Moura, Abrams, Retter, Gunnarsdottir \& Ando, 2009; van Dick et al., 2004). Prior studies have also shown the positive correlation between job satisfaction and organizational identification (Efraty \& Wolfe, 1988; van Knippenberg \& van Schie, 2000).

A high-perceived diversity climate is reflective of a bias-free workplace (i.e. in congruence with the psychological contract of fair treatment) and the organization caring about employee well-being (McKay, Avery, Tonidandel, Morris, Hernandez \& Hebl, 2007). In this regard, scholars have built upon social exchange principles and provided valuable 
OMJ 18,1

insights into the positive relationship between fair and supportive treatment of employees and employee outcomes (for a review of social exchange theory, see Cropanzano \& Mitchell, 2005), including job satisfaction and organizational identification (Edwards \& Peccei, 2010; Sluss et al., 2008). Organizations developing an inclusive diversity climate spread the belief among employees that they are a part of same group (Mor Barak et al., 2016), developing shared interests for the organization. The development of a favourable diversity climate lowers the boundaries among individuals and spreads the concept of commonality and helps employees to relate to each other. This enhances their job satisfaction and organizational identification. Therefore, it appears reasonable to predict that diversity climate is associated with an employee's job experience and propensity for organizational identification as a result of positive employee-organization exchanges. While most research has been conducted to determine the antecedents of diversity climate (Pugh et al., 2008), a growing body of literature has begun to examine the outcomes of diversity climate. For instance, diversity climate has been found to play a significant role in augmenting employees' job satisfaction and organizational commitment (Hicks-Clarke \& Iles, 2000; McKay et al., 2007; McKay, Avery, Liao, \& Morris, 2011) as well as reducing turnover intentions. Thus, we hypothesize:

H3. Diversity climate will enhance job satisfaction.

H4. Diversity climate will enhance organizational identification.

\section{Mediating role of diversity climate}

Based on the integration of our arguments derived from the signalling and social exchange theories for H1-H4 (Blau, 1964; Spence, 1973), we argue that diversity climate will provide a mechanism through which employees' perceptions of an organization's efforts to support diversity and value of diversity affect employee outcomes, including job satisfaction and organizational identification. Management research acknowledges the importance of employee perceptions of organizations' policies and actions and considers it as a key factor in forging positive employee attitudes and behaviours. As Guest (1999) observed, employee perceptions play an important role in the effects HR interventions have on individual and organizational performance. Similarly, several studies have established that employee outcomes are largely determined by employees' experience of HR practices, rather than the intended HR practices (Khilji \& Wang, 2006; Nishii, Lepak \& Schneider, 2008; Wright \& Nishii, 2007). The extent to which individuals perceive or experience the objectives and influences of HR interventions may differ (Nishii et al., 2008). Differences in individual perceptions are deemed to be contingent on several factors, including individual expectations, values, beliefs and previous experience (Den Hartog, Boselie \& Paauwe, 2004). In a more recent study on the impact of employee perceptions of HR practices on discretionary work effort (DWE) and co-worker assistance (CWA), Frenkel, Restubog and Bednall (2012) found that favourable perceptions of HR practices contributed to heightened sense of procedural and distributive justice among employees, which in turn fortified organizational identification. Under the influence of increased identification, they observed an increase in employees' obligation and genuine care about the success of their organization, promoting DWE and CWA. Thus, we hypothesize:

H5. Diversity climate will mediate the relationships between perceived efforts to support diversity and outcomes (job satisfaction and organizational identification).

H6. Diversity climate will mediate the relationships between organizational value of diversity and outcomes (job satisfaction and organizational identification). 


\section{Methods}

The study used a cross-sectional design, and data were collected through a survey of employees from an Australian manufacturing organization.

\section{Sample and data collection}

The sampling frame comprises all employees of an Australian manufacturing organization. A total of 250 employees were sent a survey in 2013. After deleting incomplete responses, 134 surveys with all or most questions answered led to a response rate of $53.6 \%$.

\section{Measures}

Predictors. Efforts to support diversity and organizational value of diversity are the actions taken by the organization, but employee-level literature measures them as perceptions of individuals. Efforts to support diversity was measured using a three-item scale originally developed by Hegarty and Dalton (1995) and refined by Triana, García, and Colella (2010), with a reported reliability of 0.75 . A sample item is "My company accommodates the needs of disabled persons". Cronbach's $\alpha$ for the current study is 0.72 . The $\alpha$ values from $0.65-0.80$ are considered adequate (Mallery \& George, 2003; Spector, 1992). A five-item scale was used to measure organizational value of diversity, as used by Avery et al. (2007), with a reported reliability of 0.89 . The reliability coefficient value of the scale for the current study is 0.85 . The sample item includes, "The head of my organization is committed to diversity at my workplace". Both scales were reported on a five-point Likert scale from " 1 " representing "strongly disagree" to "5" representing "strongly agree".

Outcomes. Job satisfaction was measured using a seven-item scale as used by King, Dawson, Kravitz and Gulick (2012), asking employees' degree of satisfaction with respect to different aspects of the job; for example, "support from immediate manager" and "value of work". The authors reported a reliability of 0.86. Employees reported on a five-point scale from "very dissatisfied" to "very satisfied". Cronbach's $\alpha$ value for the current study is 0.89 . Organizational identification was measured with Mael and Ashforth's (1995) five-item scale, with a reported reliability of 0.75 . Cronbach's $\alpha$ value for the current study is 0.85 . The representative item from the scale is, "When someone criticizes my organization, it feels like a personal insult".

Mediator. The mediating variable of diversity climate was measured with a scale used by McKay et al. (2011), with a reported reliability of 0.82. The scale comprised four items; for example, "My organization maintains a diversity-friendly work environment". The five response choices ranged from "strongly disagree" (1) to "strongly agree" (5). Cronbach's $\alpha$ for the current study is 0.85 .

Controls. The analysis controlled for the effects of gender and age. Participant gender has been coded as a dummy variable, where " 0 " = male and " 1 " = female. Age was an openended question in the survey. To convert it into a categorical variable, we calculated the median value of age and created two categories above and below the median value. Lower values were represented by " 0 ", while the upper values were represented by " 1 ". A total of $51.5 \%$ of the values lay below the median value.

\section{Results}

Table 1 presents the means, standard deviations and correlations for all the variables in the theoretical model. The cross-sectional self-reported data may have common method bias (Podsakoff, MacKenzie, Lee \& Podsakoff, 2003). Therefore, Harman's single-factor test was performed to eliminate redudnant items. The total variance explained by one factor was only $32.65 \%$, demonstrating no risk of common method bias.
Diversity climate 
OMJ

18,1

After testing the reliabilities of the constructs, AMOS was used to test the model (Figure 1). $H 1$ proposes that efforts to support diversity are positively related to diversity climate. $H 2$ states that the organizational value of diversity is positively associated with diversity climate. $H 3$ and $H 4$ anticipate the positive relationship of diversity climate with job satisfaction and organizational identification, respectively. The relationships were tested using the structural equation modelling technique in AMOS. The results indicate that efforts to support diversity do not have a significant relationship with diversity climate, leading us to reject $H 1$, whereas the relationships in $H 2, H 3$ and $H 4$ were found to be significant, with $\alpha$ values less than 0.001 . Table 2 presents the estimates and significance of the first three hypotheses.

H5 states that diversity climate will mediate the relationship between efforts to support diversity and outcomes (job satisfaction and organizational identification). The results in Table 3 indicate that the mediating relationship is non-significant, with an $\alpha$ value above the

\begin{tabular}{|c|c|c|c|c|c|c|c|c|}
\hline Variable & Mean & $\mathrm{SD}$ & 1 & 2 & 3 & 4 & 5 & 6 \\
\hline \multicolumn{9}{|l|}{ Predictors } \\
\hline 1. Efforts to support diversity & 3.08 & 0.77 & & & & & & \\
\hline 2. Organizational value of diversity & 3.48 & 0.72 & $0.69 * *$ & & & & & \\
\hline \multicolumn{9}{|l|}{ Mediator } \\
\hline 3. Diversity climate & 3.60 & 0.71 & $0.54 * *$ & $0.74^{* * *}$ & & & & \\
\hline \multicolumn{9}{|l|}{ Outcome } \\
\hline 4. Job satisfaction & 3.81 & 0.64 & $0.27 * *$ & $0.41^{* *}$ & $0.53 * *$ & & & \\
\hline 5. Organizational identification & 3.50 & 0.61 & $0.26 * *$ & $0.34^{* *}$ & $0.43 * *$ & $0.51^{* *}$ & & \\
\hline \multicolumn{9}{|l|}{ Controls } \\
\hline 6. Gender & 0.27 & 0.45 & -0.02 & 0.08 & 0.08 & 0.03 & 0.14 & \\
\hline 7. Age & 1.49 & 0.50 & -0.00 & 0.02 & -0.01 & -0.02 & 0.14 & $-0.22^{*}$ \\
\hline
\end{tabular}

Table 1.

Means, standard deviations and

Notes: $* p<0.05$ (two-tailed); $* * p<0.01$ (two-tailed)

\begin{tabular}{llc}
\hline Predictor & Outcome & Estimate \\
\hline Efforts to support diversity & Diversity climate & 0.05 \\
Organizational value of diversity & Diversity climate & $0.71 * * *$ \\
Diversity climate & Job satisfaction & $0.53 * * *$ \\
Diversity climate & Organizational identification & $0.44^{* * *}$ \\
Note: $* * * p<0.001$ & & \\
\hline
\end{tabular}

Table 2.

Direct effects

\begin{tabular}{lccl}
\hline Hypotheses & Direct effect & Indirect effect & Mediation \\
\hline ETSD-DC-JS & $0.048(\mathrm{~ns})$ & $0.026(\mathrm{~ns})$ & No mediation \\
ETSD-DC-OID & $0.018(\mathrm{~ns})$ & $0.021(\mathrm{~ns})$ & No mediation \\
OVD-DC-JS & $0.079(\mathrm{~ns})$ & $0.355^{* * *}$ & Full mediation \\
OVD-DC-OID & $0.038(\mathrm{~ns})$ & $0.281^{* *}$ & Full mediation
\end{tabular}

Table 3.

Mediation analysis
Notes: $* * * p<0.001 ; * * p<0.05 ;$ ns $=$ Not significant, ETSD = Efforts to support diversity; OVD = Organizational value of diversity; $\mathrm{DC}=$ Diversity climate; $\mathrm{JS}=$ Job satisfaction; $\mathrm{OID}=$ Organizational identification 
$10 \%$ significance level. Thus, the hypothesis is rejected. $H 6$ proposes the mediating role of diversity climate in the relationship of organizational value of diversity and outcomes (job satisfaction and organizational identification). Table 3 reports the output of $H 6$ as significant.

The final model with significant relationships is shown in Figure 2. The ratio of $\chi^{2}$ to the degrees of freedom for the model is 1.103 , which is below 3 (the maximum acceptable level), showing the model fit for the data. The root mean square error of approximation (RMSEA) value for the proposed model is 0.00 , indicating a model fit. The goodness-of-fit index (GFI) and adjusted GFI (AGFI) values for the proposed model are 0.999 and 0.996 , respectively, which shows acceptable variance for the model in the study. The values for the comparative fit index (CFI), Tucker-Lewis index (TLI), normed fit index (NFI) and RFI for the model are 1.00, 0.999, 0.997 and 0.988, respectively. All three types of indicators (parsimonious fit, absolute fit and incremental fit) show that the model is fit for the study.

\section{Discussion}

The study's main objectives were to investigate whether: efforts to support diversity and organizational value of diversity are positively related with diversity climate, diversity climate is positively associated with job satisfaction and organizational identification and diversity climate serves as the mediating mechanism in the relationship of predictors (efforts to support diversity and organizational value of diversity) and outcomes (job satisfaction and organizational identification). The results reveal significant relationships for organizational value of diversity and diversity climate, diversity climate and outcomes and for the mediating role of the organizational value of diversity-diversity climate-outcomes relationship, whereas efforts to support diversity do not show significant relationships.

\section{Direct effects}

The results indicate a positive relationship between organizational value of diversity and diversity climate. These results are consistent with the previous research that shows that valuing diversity is vital and needs to pervade throughout the organization (Gilbert \& Ivancevich, 2000; Hopkins, Hopkins \& Mallette, 2001; Ng \& Sears, 2018). This percolation is possible when organizations focus on valuing diversity in HR policies and practices, and hence, that will result in improving employees' diversity climate (Herdman \& McMillanCapehart, 2010). Our results are unique, as the direct influence of organizational value of diversity on diversity climate has not previously been measured; the effect of organizational values through HR practices remains the focus of previous research (Guzzo et al., 1994; Herdman \& McMillan-Capehart, 2010; Tsui et al., 1997). The positive association between diversity climate and job satisfaction/organizational identification is well supported by previous literature (Hicks-Clarke \& Iles, 2000; McKay et al., 2011; McKay et al., 2007).

This study did not find support for the relationship of efforts to support diversity and diversity climate. Future research can investigate the reasons for this outcome and can verify these results in different situations, such as different cultural contexts or organizational settings. There may be several reasons for this non-significant relationship.

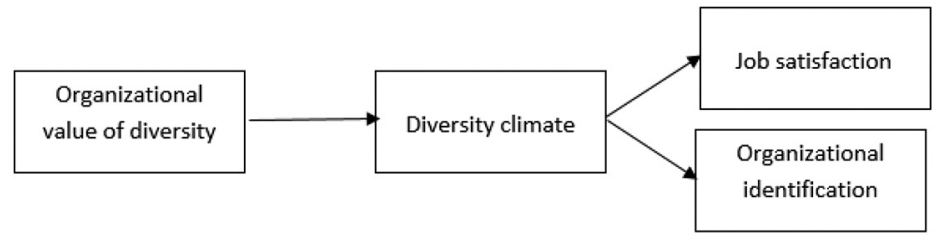

Figure 2. Model with significant relationship 
OMJ 18,1

The focus of organisation on supporting diversity may trigger discrimen perceptions among the majority employees of the organization. Employees' perception of discrimination might trigger negative exchanges under the account of the social exchange theory (Helm, Bonoma, $\&$ Tedeschi, 1972).

\section{Mediation effects}

The mediating relationship of organizational value of diversity-diversity climate-outcomes is also significant. Although the mediating relationship has not previously been tested, the findings are consistent with some extant literature reporting that organizational support in relation to employees' expectations fosters employees' sense of being valued by the organization and their self-esteem, which ultimately creates satisfaction among employees and helps them to positively identify with the organization. This fulfilment of expectations engenders a sense of obligation among employees to reciprocate in the form of favourable behaviours towards the organization (Bal et al., 2010; Cropanzano \& Mitchell, 2005). As explained by the social exchange theory that the relationships among organization and employees are two-sided and mutual (Emerson, 1976), positive signals from the organization in the form of valuing diversity contribute to heightened sense of reciprocating positive exchange behaviour in the form of enhanced job satisfaction and organizational identification.

\section{Theoretical and research contributions}

This study has several theoretical and research contributions. The findings support the signalling theory (Cropanzano \& Mitchell, 2005) and social exchange theory. The positive effect of organizational value of diversity on diversity climate and diversity climate on employee satisfaction and organizational identification strengthens the argument that positive signals by organizations will help employees to develop perceptions about the organization, and that these will be reciprocated by employees in the form of exchanging positive feedback towards the organization (Spence, 1973).

Moreover, the results of the study support the integration of the signalling and social exchange theories. The significance of the organizational value of diversity-diversity climate-outcomes relationship strengthens the belief that these two theories can be integrated into different contexts (Karasek \& Bryant, 2012). Therefore, we extend the theorising of these relationships. At the same time, the relationship between organizational value of diversity and diversity climate has not previously been studied. Therefore, the study addresses a gap in past literature by investigating the direct relationship of organizational value of diversity and diversity climate in the Australian context.

The non-significant relationship of efforts to support diversity and diversity climate needs to be further explored. The implementation of efforts to support diversity by the organization can create a sense of discrimination among majority members (non-targets) and negatively influence the diversity climate (Leslie, 2019). This also interrupts the perceptions of positive signals from the management and can lead to a negative exchange. The net effect of a positive exchange (theorized in this paper) and a negative exchange (from the majority) can be a non-significant relationship found in this research. Researchers should use larger data sets to explore the relationship of efforts to support diversity and diversity climate (Zamboni, 2018).

Furthermore, the proposed theoretical model should be tested by researchers in different cultural contexts and for different diversity types. Researchers can also explore the different employee outcomes (e.g. job dedication, turnover intention) or organizational outcomes (e.g. organizational productivity, organizational performance, organizational commitment) with 
the proposed predictors and mediating variable of diversity climate (McKay et al., 2007; Parker \& Allen, 2001; Shadur, Kienzle, \& Rodwell, 1999). A larger number of predictors of diversity climate, such as group characteristics or different diversity forms (Kossek \& Zonia, 1993), can also help understand the development of positive diversity climate within the organizations.

\section{Practical implications}

Australia is continuously welcoming a large number of immigrants each year, as stated by the Australian Human Rights Commission (Soutphommasane, 2015). As a result, investing efforts into implementing successful diversity programmes is gaining increased attention in the Australian context (Australian Maritime Safety Authority, 2014; Safe Work Australia, 2016). Therefore, research on organizational value of diversity carries significant practical implications. Understanding the impact of diversity programmes on developing diversity climate within the organization will help managers to better recognize programme success. This will help them to make changes accordingly and obtain maximum benefits from their diversity programmes.

According to B\&T Magazine (2017), Australian workers are 19 times more satisfied when working in diverse environments. This shows that if organizations value diversity, they can send positive signals to their employees, leading to positive employee attitudes and behaviours towards the organization. These positive signals will also result in enhanced employee satisfaction and increased organizational identification (Spence, 1973). Australia has also been reported as a country with lower levels of productivity (Hannan \& Gluyas, 2012), with one-fifth of the dissatisfied workers coming from the private sector (Cassells, 2017); therefore, it is important for organizations to concentrate on factors that can lead to positive perceptions in the minds of employees. The positive employee-organization exchange relationship will certainly result in positive employee and organizational outcomes. The more positive signals employees receive from the organization, the more positive attitudes they will reciprocate (Bettencourt \& Brown, 1997; Hicks-Clarke \& Iles, 2000; Mor Barak \& Levin, 2002).

The findings of this study illustrate to managers that developing a positive diversity climate through effective diversity programmes is also important for employee satisfaction particularly employees who are honoured to identify themselves with the organization (Castro \& Martins, 2010). The positive diversity climate has been found to lead to reductions in absenteeism among racial and ethnic groups (Avery et al., 2007). However, organizations' diversity initiatives can also mislead and do not produce desirable results (Leslie, 2019), or in the process of sending positive signals, negative signals can also travel unintentionally and can complicate the signalling process (Taj, 2016). Therefore, it is essential to understand the influence of these unintended signals to minimize the negative consequences. Negative signals of management's ineffectiveness about diversity can lead to dissatisfied employees with high turnover intentions (Groeneveld, 2011; McKay et al., 2007), low productivity and reduced organizational commitment and identification (Gonzalez \& DeNisi, 2009). Therefore, organizations need to make careful efforts to support diversity, which can contribute to employee satisfaction and, in turn, organizational productivity.

\section{Limitations and avenues for future research}

This study has certain limitations. First, the study considered only efforts to support diversity and organizational value of diversity as the predictors of perceptions of diversity climate; however, many other organizational factors can influence employees' perceptions of diversity climate. Future research can attempt to identify additional variables that 
account for diversity climate perceptions, such as group and organizational characteristics (Kossek \& Zonia, 1993). Second, this study was conducted in the Australian context. The impact of efforts and value of diversity on perceptions of diversity climate may differ in other cultural contexts, with different levels of diversity in their population. Third, only one manufacturing organization was included in the survey; therefore, the results may not be directly generalizable to other sectors. Also, the small sample size may limit the generalizability of the findings. Fourth, a multilevel study can be conducted to better understand the organizations' perspective on sending positive diversity signals and their impact on employees. Finally, cross-sectional design and single source data were used for this study, causing concerns for the common method variance and casual inferences. To avoid bias, respondents were ensured about the confidentiality of the data, and no personal information was asked in the survey. At the same time, Harman's single-factor test was performed to eliminate the chances of common method bias.

\section{Conclusion}

The current study contributes to the existing literature on managing diversity in the organization and perceptions of diversity climate. The results suggest that the signals provided by organizations with respect to the value of diversity add to employees' positive perceptions of diversity climate (Kossek \& Zonia, 1993; Mor Barak et al., 1998). These positive perceptions of employees encourage them to offer an exchange with the organization in the form of enhanced job satisfaction and organizational identification. The study integrates two streams of research using the signalling theory (Spence, 1973) and social exchange theory (Cropanzano \& Mitchell, 2005), which will also helps to advance the field of managing diversity.

\section{References}

Ashforth, B. \& Mael, F. (1989). Social identity theory and the organization. Academy of Management Review, 14(1), 20-39. doi: 10.5465/amr.1989.4278999.

Australian Maritime Safety Authority. (2014). Promoting diversity within AMSA's workforce: Diversity Plan 2014-2017. Retrieved from www.amsa.gov.au/sites/default/files/amsa348-diversity-plan.pdf

Avery, D., McKay, P., Wilson, D., \& Tonidandel, S. (2007). Unequal attendance: the relationships between race, organizational diversity cues, and absenteeism. Personnel Psychology, 60(4), 875-902. doi: 10.1111/j.1744-6570.2007.00094.x.

B\&T Magazine. (2017). Study: Aussie workers 19 times more satisfied in diverse workplaces. Retrieved from www.bandt.com.au/marketing/study-aussie-workers-19-times-satisfied-diverse-workplaces

Bal, P. M., Chiaburu, D. S., \& Jansen, P. G. W. (2010). Psychological contract breach and work performance: is social exchange a buffer or an intensifier?. Journal of Managerial Psychology, 25(3), 252-273.

Bettencourt, L. \& Brown, S. (1997). Contact employees: relationships among workplace fairness, job satisfaction and prosocial service behaviors. Journal of Retailing, 73(1), 39-61. doi: 10.1016/ S0022-4359(97)90014-2.

Blau, P. (1964). Exchange and Power in Social Life, New York, NY: John Wiley.

Bowen, D. \& Ostroff, C. (2004). Understanding HRM-firm performance linkages: the role of the 'strength' of the HRM system. The Academy of Management Review, 29(2), 203-221.

Cassells, R. (2017). Happy workers: How satisfied are Australians at work? Retrieved from https://bcec. edu.au/publications/happy-workers-how-satisfied-are-australians-at-work/ 
Castro, M. L. \& Martins, N. (2010). The relationship between organisational climate and employee satisfaction in a South African information and technology organization. SA Journal of Industrial Psychology, 36(1), 1-9. doi: 10.4102/sajip.v36i1.800.

Cober, R., Brown, D., Blumental, A., Doverspike, D., \& Levy, P. (2000). The quest for the qualified job surfer: It's time the public sector catches the wave. Public Personnel Management, 29(4), 479-496. doi: $10.1177 / 009102600002900406$.

Cole, B. \& Salimath, M. (2013). Diversity identity management: an organizational perspective. Journal of Business Ethics, 116(1), 151-161. doi: 10.1007/s10551-012-1466-4.

Cole, B., Jones, R., \& Russell, L. (2016). Racial dissimilarity and diversity climate effect organizational identification: Equality, diversity and inclusion. An International Journal, 35(5/6), 314-327.

Cole, M., Bruch, H., Dick, R., Becker, T., \& Meyer, J. (2006). Organizational identity strength, identification, and commitment and their relationships to turnover intention: does organizational hierarchy matter? Journal of Organizational Behavior, 27(5), 585-605. doi: 10.1002/job.378.

Cropanzano, R. \& Mitchell, M. S. (2005). Social exchange theory: an interdisciplinary review. Journal of Management, 31(6), 874-900. doi: 10.1177/0149206305279602.

Cropanzano, R., Anthony, E., Daniels, S., \& Hall, A. (2017). Social exchange theory: a critical review with theoretical remedies. Academy of Management Annals, 11(1), 479-516. doi: 10.5465/annals.2015.0099.

Cundiff, N., Nadler, J., \& Swan, A. (2009). The influence of cultural empathy and gender on perceptions of diversity programs. Journal of Leadership \& Organizational Studies, 16(1), 97-110.

De Moura, G., Abrams, D., Retter, C., Gunnarsdottir, S., \& Ando, K. (2009). Identification as an organizational anchor: how identification and job satisfaction combine to predict turnover intention. European Journal of Social Psychology, 39(4), 540-557. doi: 10.1002/ejsp.553.

Den Hartog, D., Boselie, P., \& Paauwe, J. (2004). Performance management: a model and research agenda. Applied Psychology, 53(4), 556-569. doi: 10.1111/j.1464-0597.2004.00188.x.

Dobbin, F., Kalev, A., \& Kelly, E. (2007). Diversity management in corporate. Contexts, 6(4), 21-27. doi: $10.1525 /$ ctx.2007.6.4.21.

Downey, S., Werff, L., Thomas, K., \& Plaut, V. (2015). The role of diversity practices and inclusion in promoting trust and employee engagement. Journal of Applied Social Psychology, 45(1), 35-44. doi: 10.1111/jasp.12273.

Dwertmann, D. \& Boehm, S. (2016). Status matters: the asymmetric effects of supervisor-subordinate disability incongruence and climate for inclusion. Academy of Management Journal, 59(1), 44-64. doi: 10.5465/amj.2014.0093.

Edwards, M. (2009). HR, perceived organisational support and organisational identification: an analysis after organisational formation. Human Resource Management Journal, 19(1), 91-115. doi: 10.1111/j.1748-8583.2008.00083.x.

Edwards, M. \& Peccei, R. (2010). Perceived organizational support, organizational identification, and employee outcomes: Testing a simultaneous multifoci model. Journal of Personnel Psychology, 9(1), 17-26. doi: 10.1027/1866-5888/a000007.

Efraty, D. \& Wolfe, D. (1988). The effect of organizational identification on employee affective and performance responses. Journal of Business and Psychology, 3(1), 105-112. doi: 10.1007/ BF01016752.

Emerson, R. M. (1976). Social exchange theory. Annual Review of Sociology, 2(1), 335-362. doi: 10.1146/ annurev.so.02.080176.002003.

Frenkel, S., Restubog, S., \& Bednall, T. (2012). How employee perceptions of HR policy and practice influence discretionary work effort and co-worker assistance: evidence from two organizations. The International Journal of Human Resource Management, 23(20), 4193-4210. doi: 10.1080/ 09585192.2012.667433.

Gilbert, J. \& Ivancevich, J. (2000). Valuing diversity: a tale of two organizations. The Academy of Management Executive, 14(1), 93-105. 
OMJ 18,1

Gonzalez, J. \& Denisi, A. (2009). Cross-level effects of demography and diversity climate on organizational attachment and firm effectiveness. Journal of Organizational Behavior, 30(1), 21-40. doi: 10.1002/job.498.

Gould-Williams, J. (2007). HR practices, organizational climate and employee outcomes: evaluating social exchange relationships in local government. The International Journal of Human Resource Management, 18(9), 1627-1647. doi: 10.1080/09585190701570700.

Groeneveld, S. (2011). Diversity and employee turnover in the Dutch public sector: does diversity management make a difference?. International Journal of Public Sector Management, 24(6), 594-612. doi: 10.1108/09513551111163675.

Guest, D. (1999). Human resource management - the workers' verdict. Human Resource Management Journal, 9(3), 5-25. doi: 10.1111/j.1748-8583.1999.tb00200.x.

Guzzo, R., Noonan, K., \& Elron, E. (1994). Expatriate managers and the psychological contract. Journal of Applied Psychology, 79(4), 617. doi: 10.1037/0021-9010.79.4.617.

Hannan, E. \& Gluyas, R. (2012). Productivity Gap "Holding Back Growth" as Survey Ranks Australia Second Last, The Australian.

Hegarty, W. H. \& Dalton, D. R. (1995). Development and psychometric properties of the organizational diversity inventory (ODI). Educational and Psychological Measurement, 55(6), 1047-1052. doi: $10.1177 / 0013164495055006014$.

Helm, B., Bonoma, T. V., \& Tedeschi, J. T. (1972). Reciprocity for harm done. The Journal of Social Psychology, 87(1), 89-98. doi: 10.1080/00224545.1972.9918651.

Herdman, A. \& McMillan-Capehart, A. (2010). Establishing a diversity program is not enough: exploring the determinants of diversity climate. Journal of Business and Psychology, 25(1), 39-53. doi: 10.1007/s10869-009-9133-1.

Hicks-Clarke, D. \& Iles, P. (2000). Climate for diversity and its effects on career and organisational attitudes and perceptions. Personnel Review, 29(3), 324-345.

Holly Buttner, E., Lowe, K., \& Billings-Harris, L. (2010). Diversity climate impact on employee of color outcomes: Does justice matter? Career Development International, 15(3), 239-258. doi: 10.1108/ 13620431011053721.

Hopkins, W., Hopkins, S., \& Mallette, P. (2001). Diversity and managerial value commitment: A test of some proposed relationships. Journal of Managerial Issues, 13(3), 288-306.

Karasek, R. \& Bryant, P. (2012). Signaling theory: past, present and future. Academy of Strategic Management Journal, 11(1), 91-99.

Khilji, S. \& Wang, X. (2006). 'Intended' and 'implemented' HRM: The missing linchpin in strategic human resource management research. The International Journal of Human Resource Management, 17(7), 1171-1189. doi: 10.1080/09585190600756384.

Kim, S. \& Gelfand, M. (2003). The influence of ethnic identity on perceptions of organizational recruitment. Journal of Vocational Behavior, 63(3), 396-416. doi: 10.1016/S0001-8791(02)00043-X.

King, E. B., Dawson, J. F., Kravitz, D. A., \& Gulick, L. M. V. (2012). A multilevel study of the relationships between diversity training, ethnic discrimination and satisfaction in organizations. Journal of Organizational Behavior, 33(1), 5-20. doi: 10.1002/job.728.

Klarsfeld, A., Ng, E., \& Tatli, A. (2012). Social regulation and diversity management: A comparative study of France, Canada and the UK. European Journal of Industrial Relations, 18(4), 309-327. doi: 10.1177/0959680112461091.

Kossek, E. \& Zonia, S. (1993). Assessing diversity climate: A field study of reactions to employer efforts to promote diversity. Journal of Organizational Behavior, 14(1), 61-81. doi: 10.1002/ job.4030140107.

Kossek, E., Markel, K., \& Mchugh, P. (2003). Increasing diversity as an HRM change strategy. Journal of Organizational Change Management, 16(3), 328-352. 
Leslie, L. M. (2019). Diversity initiative effectiveness: A typological theory of unintended consequences. Academy of Management Review, 44(3), 538-563. doi: 10.5465/amr.2017.0087.

Locke, E. A. (1976). The nature and causes of job satisfaction. In M.D. Dunnette \& L.M. Hough (Eds), Handbook of Industrial and Organizational Psychology, Palo Alto, Calif: Consulting Psychologists Press.

McDonald, R. P. \& Ho, M. H. R. (2002). Principles and practice in reporting structural equation analyses. Psychological Methods, 7(1), 64. doi: 10.1037/1082-989X.7.1.64.

McKay, P. F., Avery, D. R., Liao, H., \& Morris, M. A. (2011). Does diversity climate lead to customer satisfaction? It depends on the service climate and business unit demography. Organization Science, 22(3), 788-803. doi: 10.1287/orsc.1100.0550.

McKay, P., Avery, D., Tonidandel, S., Morris, M., Hernandez, M., \& Hebl, M. (2007). Racial differences in employee retention: Are diversity climate perceptions the key? Personnel Psychology, 60(1), 35-62. doi: 10.1111/j.1744-6570.2007.00064.x.

Mael, F. A. \& Ashforth, B. E. (1995). Loyal from day one: Biodata, organizational identification, and turnover among newcomers. Personnel Psychology, 48(2), 309-309. doi: 10.1111/j.1744-6570.1995. tb01759.x.

Mallery, P. \& George, D. (2003). SPSS for Windows Step by Step: A Simple Guide and Reference, Bacon: Allyn.

Miller, T. \& Del Carmen Triana, M. (2009). Demographic diversity in the boardroom: mediators of the board diversity-firm performance relationship. Journal of Management Studies, 46(5), 755-786. doi: 10.1111/j.1467-6486.2009.00839.x.

Mor Barak, M. E. \& Levin, A. (2002). Outside of the corporate mainstream and excluded from the work community: a study of diversity, job satisfaction and well-being. Community, Work \& Family, 5(2), 133-157.

Mor Barak, M., Cherin, D., \& Berkman, S. (1998). Organizational and personal dimensions in diversity climate: ethnic and gender differences in employee perceptions. The Journal of Applied Behavioral Science, 34(1), 82-104. doi: 10.1177/0021886398341006.

Mor Barak, M. E., Lizano, E. L., Kim, A., Duan, L., Rhee, M.-K., Hsiao, H.-Y., \& Brimhall, K. C. (2016). The promise of diversity management for climate of inclusion: A state-of-the-art review and meta-analysis. Human Service Organizations: Management, Leadership \& Governance, 40(4), 305-333.

Ng, E. \& Sears, G. (2018). Walking the talk on diversity: CEO beliefs, moral values, and the implementation of workplace diversity practices. Journal of Business Ethics, 1-14.

Nishii, L. (2013). The benefits of climate for gender-diverse groups. Academy of Management Journal, 56(6), 1754-1774. doi: 10.5465/amj.2009.0823.

Nishii, L., Lepak, D., \& Schneider, B. (2008). Employee attributions of the 'why' of HR practices: their effects on employee attitudes and behaviors, and customer satisfaction. Personnel Psychology, 61(3), 503-545. doi: 10.1111/j.1744-6570.2008.00121.x.

Parker, L. \& Allen, T. D. (2001). Work/family benefits: Variables related to employees' fairness perceptions. Journal of Vocational Behavior, 58(3), 453-468. doi: 10.1006/jvbe.2000.1773.

Patten, S. (2019). Companies wasting millions on diversity programs. Retrieved from www.afr.com/ leadership/management/companies-wasting-millions-on-diversity-programs-20190719-p528ry

Podsakoff, P. M., MacKenzie, S. B., Lee, J.-Y., \& Podsakoff, N. P. (2003). Common method biases in behavioral research: A critical review of the literature and recommended remedies. Journal of Applied Psychology, 88(5), 879-903. doi: 10.1037/0021-9010.88.5.879.

Pugh, S., Dietz, J., Brief, A., \& Wiley, J. (2008). Looking inside and out: the impact of employee and community demographic composition on organizational diversity climate. Journal of Applied Psychology, 93(6), 1422-1428. doi: 10.1037/a0012696. 
Rhoades, L. \& Eisenberger, R. (2002). Perceived organizational support: A review of the literature. Journal of Applied Psychology, 87(4), 698-714. doi: 10.1037/0021-9010.87.4.698.

Riketta, M. (2005). Organizational identification: A meta-analysis. Journal of Vocational Behavior, 66(2), 358-384. doi: 10.1016/j.jvb.2004.05.005.

Rynes, S., Bretz, R., \& Gerhart, B. (1991). The importance of recruitment in job choice: A different way of looking. Personnel Psychology, 44(3), 487-521. doi: 10.1111/j.1744-6570.1991.tb02402.x.

Safe Work Australia. (2016). Diversity and inclusion strategy and action plans 2016-2019. Retrieved from www.safeworkaustralia.gov.au/system/files/documents/1704/swa-diversity-and-inclusionstrategy-2016-19.pdf

Schneider, B. \& Reichers, A. (1983). On the etiology of climates. Personnel Psychology, 36(1), 19-39. doi: 10.1111/j.1744-6570.1983.tb00500.x.

Schneider, B., Gunnarson, S., \& Niles-Jolly, K. (1994). Creating the climate and culture of success. Organizational Dynamics, 23(1), 17-29. doi: 10.1016/0090-2616(94)90085-X.

Schumacker, R. E. \& Lomax, R. G. (2004). A beginner's Guide to Structural Equation Modeling, London: Psychology press.

Settoon, R., Bennett, N., \& Liden, R. (1996). Social exchange in organizations: Perceived organizational support, leader-member exchange, and employee reciprocity. Journal of Applied Psychology, 81(3), 219-227. doi: 10.1037/0021-9010.81.3.219.

Shadur, M. A., Kienzle, R., \& Rodwell, J. J. (1999). The relationship between organizational climate and employee perceptions of involvement: The importance of support. Group \& Organization Management, 24(4), 479-503.

Shen, J., Chanda, A., D’Netto, B., \& Monga, M. (2009). Managing diversity through human resource management: An international perspective and conceptual framework. The International Journal of Human Resource Management, 20(2), 235-251. doi: 10.1080/09585190802670516.

Sluss, D., Klimchak, M., \& Holmes, J. (2008). Perceived organizational support as a mediator between relational exchange and organizational identification. Journal of Vocational Behavior, 73(3), 457-464. doi: 10.1016/j.jvb.2008.09.001.

Soutphommasane, T. (2015). Cultural diversity in the workplace. Retrieved from www.humanrights.gov. $\mathrm{au} / \mathrm{about} /$ news/speeches/cultural-diversity-workplace-0

Spector, P. (1992). Summated Rating Scale Construction: An Introduction, Thousand Oaks, CA: Sage Publications.

Spence, M. (1973). Job market signaling. The Quarterly Journal of Economics, 87(3), 355-374. doi: 10.2307/1882010.

Spence, M. (2002). Signaling in retrospect and the informational structure of markets. American Economic Review, 92(3), 434-459. doi: 10.1257/00028280260136200.

Suazo, M., Martínez, P., \& Sandoval, R. (2009). Creating psychological and legal contracts through human resource practices: A signaling theory perspective. Human Resource Management Review, 19(2), 154-166. doi: 10.1016/j.hrmr.2008.11.002.

Taj, S. A. (2016). Application of signaling theory in management research: Addressing major gaps in theory. European Management Journal, 34(4), 338-348. doi: 10.1016/j.emj.2016.02.001.

Triana, M. \& García, M. (2009). Valuing diversity: A group-value approach to understanding the importance of organizational efforts to support diversity. Journal of Organizational Behavior, 30(7), 941-962. doi: 10.1002/job.598.

Triana, M. D C., García, M. F., \& Colella, A. (2010). Managing diversity: How organizational efforts to support diversity moderate the effects of perceived racial discrimination on affective commitment. Personnel Psychology, 63(4), 817-843. doi: 10.1111/j.1744-6570.2010.01189.x.

Tsui, A., Pearce, J., Porter, L., \& Tripoli, A. (1997). Alternative approaches to the employeeorganization relationship: Does investment in employees pay off? Academy of Management Journal, 40(5), 1089-1121. doi: 10.5465/256928. 
Turban, D. \& Greening, D. (1997). Corporate social performance and organizational attractiveness to prospective employees. Academy of Management Journal, 40(3), 658-672.

Tyler, T. \& Blader, S. (2003). The group engagement model: Procedural justice, social identity, and cooperative behavior. Personality and Social Psychology Review, 7(4), 349-361. doi: 10.1207/ S15327957PSPR0704_07.

United Nations. (2020). Sustainable development goals. Retrieved from www.un.org/sustainabledevelopment/ sustainable-development-goals/

Valcour, M., Ollier-Malaterre, A., Matz-Costa, C., Pitt-Catsouphes, M., \& Brown, M. (2011). Influences on employee perceptions of organizational work-life support: Signals and resources. Journal of Vocational Behavior, 79(2), 588-595. doi: 10.1016/j.jvb.2011.02.002.

Van Dick, R., Christ, O., Stellmacher, J., Wagner, U., Ahlswede, O., Grubba, C., Hauptmeier, M., Hoehfeld, C., Moltzen, K. \& Tissington, P.A. (2004). Should I stay or should I go? Explaining turnover intentions with organizational identification and job satisfaction. British Journal of Management, 15(4), 351-360. doi: 10.1111/j.1467-8551.2004.00424.x.

van Knippenberg, D. \& van Schie, E. (2000). Foci and correlates of organizational identification. Journal of Occupational and Organizational Psychology, 73(2), 137-147. doi: 10.1348/096317900166949.

Wright, P. M. \& Nishii, L. H. (2007). Strategic HRM and organizational behavior: Integrating multiple levels of analysis. Technical Report 07-03, CAHRS at Cornell University. Retrieved from https:// digitalcommons.ilr.cornell.edu/cgi/viewcontent.cgi?article=1404\&context=cahrswp

Zamboni, J. (2018). The advantages of a large sample size. Retrieved from https://sciencing.com/ advantages-large-sample-size-7210190.html

\section{About the authors}

Sadia Mansoor (PhD candidate, QUT) is a higher degree research student at the QUT Business School, Queensland University of Technology, Brisbane, Australia. Her research interests are demographic diversity, diversity climate perceptions and human resource practices. Her $\mathrm{PhD}$ project focuses on multilevel effects of demographic diversity at group and individual levels. She has published in quality journals, such as Management Research Review, International Journal of Organizational Diversity and World Applied Sciences Journal. She can be contacted at sadia. mansoor@hdr.qut.edu.au.

Phuong Anh Tran (MBus, QUT) is a Sessional Academic at the QUT Business School, Queensland University of Technology, Brisbane, Australia. Her research interests are demographic diversity, diversity climate perceptions and work-life programs. Her major accomplishments include the Triple Crown Scholarship from QUT Business School and First Place at 2018 Carlson International HR Case Competition, University of Minnesota, Minneapolis, USA. She can be contacted at p30.tran@qut.edu.au.

Muhammad Ali (PhD, Melbourne University) is a Senior Lecturer in the QUT Business School, Queensland University of Technology, Brisbane, Australia. His research focuses on how workforce diversity management practices and work-life programs are linked to individual and organizational effectiveness. He has published in quality journals, such as Human Resource Management, Journal of Business Ethics and Human Resource Management Journal. Muhammad Ali is the corresponding author and can be contacted at:m3.ali@qut.edu.au

For instructions on how to order reprints of this article, please visit our website: www.emeraldgrouppublishing.com/licensing/reprints.htm Or contact us for further details: permissions@emeraldinsight.com 